通年開催の介護予防教室参加者におけるフレイル・サルコペニアの 発生状況の調査とプレフレイルに関連する因子の検証 一JST 版活動能力指標に着目して一

\title{
Investigation of the occurrence situation of frailty·sarcopenia in participants in a care prevention program held throughout the year and examined the factors related to prefrailty : focusing on The Japan Science and Technology Agency Index of Competence.
}

\author{
岩村 真樹1), 安藤 卓 ${ }^{1)}$, 大和 洋輔 ${ }^{1}$, 梶本 浩之 ${ }^{11}$ \\ 新保 健次 ${ }^{1)}$, 何川渉 ${ }^{1)}$, 熊田 仁1)
}

Masaki Iwamura $^{1)}$, Suguru Ando ${ }^{1)}$, Yosuke Yamato ${ }^{1)}$, Hiroyuki Kajimoto ${ }^{11}$

Kenji Shinbo $^{1)}$, Wataru Nanikawa ${ }^{1)}$, Hitoshi Kumada ${ }^{1)}$

\begin{abstract}
要旨：通年開催の介護予防教室参加者におけるフレイルとサルコペニアの発生状況を調査 した。また,プレフレイルに関連する因子を抽出することを目的とした。対象は茨木市介 護予防教室へ参加登録している114名とした。介護予防教室参加状況, 身体機能, 筋肉量, 高次生活機能を調査し, フレイル・サルコペニア判定を行った。さらにプレフレイルに関 連する因子をロジスティック回帰分析にて解析した。調查の結果, プレフレイル $39.4 \%$, フレイル0.8\%，プレサルコペニア $31.5 \%$ ，サルコペニア4.3\%の判定割合であった。ロジ スティック回帰分析の結果, プレフレイルの関連因子として JST 版活動能力指標 (The Japan Science and Technology Agency Index of Competence) の下位領域である生活マネ ジメントと過去 1 年間の入院歷が抽出された。本研究の結果, 通年開催の介護予防教室参 加者のフレイル・サルコペニア判定割合は全国平均よりも低く, プレフレイルの予防には 健康状態に合わせて, 生活マネジメント能力に焦点を当てる必要性が示唆された。
\end{abstract}

キーワード：介護予防教室，プレフレイル，JST 版活動能力指標

Abstract: This study investigated the incidence of frailty and sarcopenia in participants in a year-round care prevention program and examined the factors related to prefrailty. There were 114 participants ( 82 women and $32 \mathrm{men}$ ) who were registered in the care prevention program held by the city of Ibaraki. Care prevention program participation status, physical function, muscle mass, and higher living functions were investigated and evaluation of sarcopenia frailty was carried out. Furthermore, factors related to prefrailty were analyzed using logistic regression analysis. The survey results showed prefrailty in $39.4 \%$, frailty in $0.8 \%$, presarcopenia in $31.5 \%$, and sarcopenia in $4.3 \%$ of participants. Logistic regression analysis showed that life management score which is the lower area of the Japan Science and Technology Agency Index of Competence, and hospital history in the past year were the factors most related to prefrailty. In conclusion, participants in the yearround care prevention program had a low incidence of frailty and sarcopenia. The results suggest that prefrailty prevention efforts should be focused on health condition and life management ability.

Key words: care prevention program, prefrailty, JST-IC

受付日：2018年 9 月15日，採択日：2018年11月19日

藍野大学医療保健学部理学療法学科：=567-0012 大阪府茨木市東太田 4- 5 - 4

Tel : 072-627-1711 FAX : 072-627-1753 E-mail : m-iwamura@pt-u.aino.ac.jp

Department of Physical Therapy, Faculty of Health Science, Aino University

4-5-4, Higashioda,Ibaraki-city, 567-0012, Japan 


\section{I 。はじめに}

現在日本は超高齢社会を迎えている。特に団塊の世 代が75歳以上となる2025年から高齢者人口の増加は顕 著となり，2065年には高齢化率は $38.4 \%$ に達し，1人 の高齢者を1.3人の現役世代が支える比率になるとい われている1。そのため, 超高齢社会への対策として, 適切な介護予防を行い，健康寿命の延伸を行うことは 喫緊の課題である。

要介護に至る過程には段階があり, 健常な状態から フレイルという状態を経て要介護に至るとされてい る2)。フレイルとは「加齢に伴う種々の機能低下を基 盤とし, 種々の健康障害に対する脆弱性が高まってい る状態」と定義司されており, 適切な介入を行うこと で健常な状態へ戻すことが可能とされている。フレイ ルに至る要因は栄養状態不良や活動量低下，活力の低 下など多岐に渡り，これらが相互に絡み合い，悪循環 が生じることで心身機能を加速的に低下させる。この ような悪循環を呈することをフレイルサイクルと呼ん で扮り, フレイルサイクルの中心的なコンポーネント としてサルコペニアがある4)。サルコペニアは European Working Group on Sarcopenia in Older People に より「身体的な障害や生活の質の低下，および死など の有害な転帰のリスクを伴うものであり，進行性およ び全身性の骨格筋量および骨格筋力の低下を特徵とす る症候群」と定義 ${ }^{5}$ されている。フレイルとサルコペ ニアはそれぞれにその前駆状態を表すプレフレイル． プレサルコペニアが定義付けられており ${ }^{315)}$ ，フレイ ル・サルコペニアに至るまでの過程で対象者を抽出す ることが可能である。

高齢者がフレイルあるいはサルコペニアを呈した状 態は，すでにフレイルサイクルへ陥っている状態であ り, 急速に状態の悪化を招く可能性がある。そのため, プレフレイル・プレサルコペニアの段階で検出し介入 することが，今後の介護予防に抒いて最も重要となる と考えられる。

本研究は通年開催の介護予防教室参加者におけるフ レイル・サルコペニアの発生状況を明らかにするとと もに, プレフレイル・プレサルコペニアの関連因子を 抽出することを目的とした。

\section{II. 対象および方法}

1. 研究デザイン

研究デザインは横断調查とした。

\section{2. 対 象}

1 ) 対象と除外基準

対象は茨木市保健医療センターで開催されている介 護予防教室へ任意で登録されている高齢者とし，登録 者全員へ郵送で参加を呼びかけた。

介護予防教室への登録は市の広報誌などを通じて呼 びかけられており，登録できない基準として心筋梗 塞・脳卒中を最近 6 ケ月以内に発症したもの, 狭心 症・ 心不全・重症不整脈のあるもの, 収縮期血圧 180 $\mathrm{mmHg}$ 以上または拡張期血圧 $120 \mathrm{mmHg}$ 以上の高血 圧のもの, 慢性閉塞性肺疾患での息切れ・呼吸困難が あるもの，糖尿病で重篤な合併症のあるもの，急性期 の関節痛・関節炎・腰痛・神経症状のあるもの, 急性 期の肺炎・肝炎などの炎症のあるもの，その他運動に よって健康状態が急変あるいは悪化する危険性がある ものであった。

調査は第 1 期と第 2 期に分け実施した。第 1 期の参 加者は91名であり，そのうちの介護予防教室未登録 1 名, ペースメーカーあり 1 名, 収縮期血圧 $180 \mathrm{mmHg}$ 以上であった 1 名の計 3 名は調査対象より除外した。 さらに調查後にデータ欠損を有した 1 名を除いた 87 名 を第 1 期調査対象者とした。第 2 期調査の参加者は93 名であり，そのうち収縮期血圧 $180 \mathrm{mmHg}$ 以上であっ た 1 名と既に第 1 期調查へ参加された 65 名を調査対象 から除いた 27 名を第 2 期調查対象者とし，第 1 期調査 と第 2 期調查対象者合計の 114 名（女性82名, 男性32 名）を最終的な解析対象とした（図 1 )。

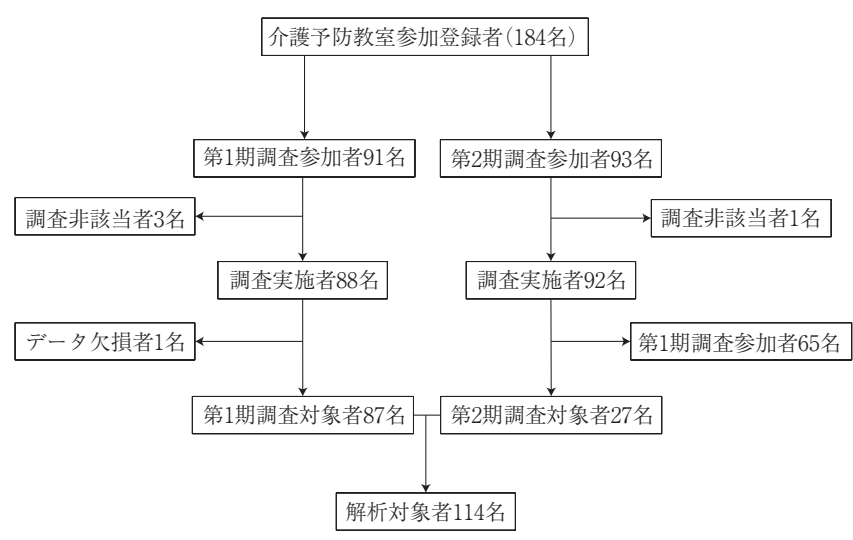

図 1 調査対象者の抽出過程

2 ）茨木市介護予防教室について

茨木市介護予防教室は茨木市保健医療センターにて 行われている取り組みであり，常時約200名の登録が ある。参加登録を行えば週 5 日（月曜日〜金曜日）午 前と午後にそれぞれ 1 時間30分行われている教室へい つでも参加することが可能である。教室はレジスタン 
ストレーニングを中心に行うクラス (Resistance Training class : 以下 RT class) とエアロビクスダン スを中心に行うクラス (Aerobics Dance class：以下 $\mathrm{AD}$ class）があり，参加登録者は任意でクラスを選択 し, 自由に参加することが可能である。また各クラス は併用することも可能である。

3 ）倫理的配慮

本研究はヘルシンキ宣言にしたがい実施した。すべ ての対象者に本研究の趣旨を説明し, 研究実施の承諾 を得た後に口頭および書面にて同意を得た。収集した デー夕は個人の特定化が行えないように直ちに連結可 能匿名化を行った。

なお, 本研究は藍野大学研究倫理委員会の承認を得 て実施した（承認番号2017-006）。

\section{3. 方 法}

1）基本情報の収集

対象者の基本情報として, 年齢 - 性別 - 身長 - 体 重・血圧を収集し、アンケートとして現在通院中の疾 患の有無, 過去 1 年間の入院歴の有無・配偶者の有 無・飲酒習慣の有無・喫煙習慣の有無についての情報 を収集した。また，介護予防教室の参加状況は，参加 教室（RT class あるいは AD class, 両方参加してい る場合は RT and $\mathrm{AD}$ class) ·参加頻度（週 1 回未満 あるいは週 1 回以上）・参加期間（初回参加日からの 経過が 6 ケ月未満あるいは 6 ケ月以上）の情報を収集 した。

\section{2 ) 高次生活機能評価}

地域で自立して活動的に日常生活を送るために必要 な能力を測る指標として, 鈴木らが開発した JST 版 活動能力指標 (The Japan Science and Technology Agency Index of Competence : 以下 JST-IC) ${ }^{6 / 7}$ を用い て高齢者の高次生活機能の評価を行った。

JST-IC は, 「新機器利用」「情報収集」「生活マネジ メント」「社会参加」という 4 つの下位領域各 4 問の 全16問で構成されており，「はい」を1点，「いいえ」 を 0 点として得点が高いほどそれぞれの領域の活動能 力が高く, 積極的に活動していることを意味する。得 点は16点満点であるが, 下位領域毎の点数も算出可能 であり, 本研究では合計得点と下位領域毎の得点を解 析に用いた。

\section{3 ) 身体機能測定}

筋肉量, 握力, 通常歩行速度の測定を行った。筋肉 量測定は生体電気インピーダンス法にて行った。使用
機器は体成分分析装置（InBody S10，インボディ・ ジャパン社製）を用いた。測定值は四肢筋肉量の合計 を身長の 2 乗にて除した值である骨格筋量指標 (Skeletal Muscle Mass Index : 以下 SMI）とした5)。 握力は鈴木ら ${ }^{8)}$ の方法に従い, 握力計 (Digital Handgrip Meter KEEP，マクロス社製）を用い立位で測定した。 測定は左右 2 回ずつ行い, 左右の最大值の平均を握力 值とした。通常歩行速度は $6 \mathrm{~m}$ の歩行路（加速路と 減速路は別に $1 \mathrm{~m}$ ずつ設定）でストップウォッチに て測定し， 2 回測定したうちの最速值を歩行速度の代 表值とした。

\section{4) フレイル・サルコペニア判定}

フレイルの判定はFried ら゙により提唱された評価 方法を日本人に適用できるように長寿医療研究開発事 業が修正した日本版 CHS 基準（Japanese version of the Cardiovascular Health Study criteria : 以下 J-CHS 基準 $)^{9}$ を使用した。J-CHS 基準の評価項目は「体重減 少」「倦怠感」「活動量」「握力」「通常歩行速度」の 5 項目であり,この 5 項目のうち 3 項目以上に該当すれ ば「フレイル」，1２項目に該当すれば「プレフレ イル」と判定した。

サルコペニアの判定は Asian Working Group for Sarcopenia（以下 AWGS ${ }^{10)}$ の評価基準を用いた。評 価項目は「筋肉量」「通常歩行速度」「握力」であり, 筋肉量低下のみ有する場合を「プレサルコペニア」, 筋肉量低下に通常歩行速度あるいは握力の低下のいず れかが伴う，あるいは双方を伴う場合を「サルコペニ ア」と判定した。

\section{4. 統計解析}

本研究では, フレイル・サルコペニアと判定された 者が少なかったため，これらに該当するものを除き， 対象者を健常群とプレフレイル群，健常群とプレサル コペニア群に分け，基本情報(年齢・性別)，アンケー 卜（現在通院中の疾患の有無・過去 1 年間の入院歴の 有無・配偶者の有無・飲酒習慣の有無・喫煙習慣の有 無), JST-IC 下位 4 領域得点(新機器利用・情報収集 · 生活マネジメント・社会参加）・JST-IC 合計得点（以 下：JST 合計）, 介護予防教室参加状況（参加教室 · 参加頻度 ·参加期間）の群間比較を行なった。健常群 とプレフレイル群および健常群とプレサルコペニア群 の比較のために Shapiro-Wilk 検定にて正規性を調心゙ た。健常群とプレフレイル群および健常群とプレサル コペニア群の比較について, 年齢・社会参加・JST 合 
計は正規性が棄却されたため, それらの比較には Mann-WhitneyのU 検定を用いた。健常群とプレサ ルコペニア群の比較について, 新機器利用・生活マネ ジメントは正規性が認められたが, Levene 検定にて 等分散性が棄却されたため, それらの比較には Welch の $\mathrm{t}$ 検定を用いた。健常群とプレフレイル群の比較に おける新機器利用・情報収集・生活マネジメントおよ び健常群とプレサルコペニア群の比較における情報収 集は正規性と等分散性のどちらも認められたため, そ れらの比較にはStudentの $\mathrm{t}$ 検定を用いた。性別, ア ンケート（現在通院中の疾患の有無・過去 1 年間の入 院歴の有無・配偶者の有無・飲酒習慣の有無・喫煙習 慣の有無), 介護予防教室参加状況 (参加教室・参加 頻度 ·参加期間）は, 期待度数が 5 より少ないセルを 有した健常群とプレフレイル群の比較掞よび健常群と プレサルコペニア群の比較における過去 1 年間に入院
歴あり・喫煙習慣あり・RT and $\mathrm{AD}$ class は Fisher の直接確率検定, その他の項目はカイ二乗検定にて解 析した。次にプレフレイルの有無を従属変数, 健常群 とプレフレイル群との群間比較で有意差の認められた 過去 1 年間に入院歴あり・生活マネジメント・JST 合 計を独立変数, 年齢・性別を調整因子としてロジス ティック回帰分析のステップワイズ法を用いて解析し た。なお，健常群とプレサルコペニア群では有意差を 認めた項目がなかったためロジスティック回帰分析は 行わなかった。ロジスティック回帰分析の適合性は Hosmer-Lemeshow 検定で判断した。

すべての統計解析は IBM SPSS Statistics (Ver. 20) を用いて行い，有意水準は $5 \%$ とした。

\section{III. 結 果}

対象者の特徵を表 1 に示す。フレイル・サルコペニ

表 1 対象者の特徵

\begin{tabular}{|c|c|c|c|}
\hline & 全体（ $\mathrm{n}=114 ）$ & 女性（n=82） & 男性（ $\mathrm{n}=32 ）$ \\
\hline \multicolumn{4}{|l|}{ 基本情報 } \\
\hline 年齢. 歳 & $73.2 \pm 4.6$ & $72.5 \pm 4.5$ & $74.8 \pm 4.7$ \\
\hline 身長. m & $1.56 \pm 0.07$ & $1.53 \pm 0.05$ & $1.64 \pm 0.04$ \\
\hline 体重. kg & $55.2 \pm 9.2$ & $51.9 \pm 7.5$ & $63.4 \pm 8.0$ \\
\hline \multicolumn{4}{|l|}{ アンケート結果 } \\
\hline 現在治療中の疾患あり。人（\%） & $67(58.7)$ & $42(51.3)$ & $25(78.1)$ \\
\hline 過去 1 年間に入院歴あり。人 (\%) & $12(10.5)$ & $8(9.8)$ & $4(12.5)$ \\
\hline 配偶者あり。人（\%） & $79(69.2)$ & $51(62.2)$ & $28(87.5)$ \\
\hline 喫煙習慣あり。人（％) & $5(4.3)$ & $0(0.0)$ & $5(15.6)$ \\
\hline 飲酒習慣あり。人（\%) & $22(19.2)$ & $9(11.0)$ & $13(40.6)$ \\
\hline \multicolumn{4}{|l|}{ 介護予防教室参加状況 } \\
\hline \multirow{3}{*}{$\begin{array}{ll}\text { RT class. 人 (\%) } \\
\text { 参加教室 } & \text { AD class. 人 (\%) } \\
& \text { RT and AD class. 人 (\%) }\end{array}$} & $38(33.3)$ & $16(19.5)$ & $22(68.7)$ \\
\hline & $69(60.5)$ & $61(74.3)$ & $8(25.0)$ \\
\hline & $7(6.1)$ & $5(6.0)$ & $2(6.2)$ \\
\hline \multirow{2}{*}{$\begin{array}{l}\text { 参加頻度 } 1 \text { 回以上／週. 人 (\%) } \\
\text { 初回参加日ょり } 6 \text { ケ月以上経過. 人 (\%) }\end{array}$} & $88(77.1)$ & $63(76.8)$ & $25(78.1)$ \\
\hline & $86(75.4)$ & $60(73.2)$ & $26(81.2)$ \\
\hline \multicolumn{4}{|l|}{ 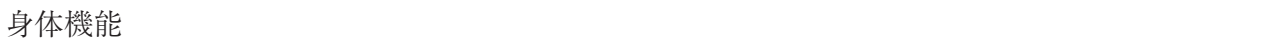 } \\
\hline 歩行速度. $\mathrm{m} / \mathrm{sec}$ & $1.40 \pm 0.21$ & $1.41 \pm 0.20$ & $1.36 \pm 0.22$ \\
\hline 握力. kg & $27.1 \pm 7.3$ & $23.3 \pm 3.7$ & $36.7 \pm 5.3$ \\
\hline \multicolumn{4}{|l|}{ 体組成 } \\
\hline SMI. $\mathrm{kg} / \mathrm{m}^{2}$ & $6.32 \pm 0.89$ & $5.92 \pm 0.55$ & $7.34 \pm 0.75$ \\
\hline JST-IC. 点 & $12.3 \pm 2.7$ & $12.5 \pm 2.5$ & $11.9 \pm 3.1$ \\
\hline \multicolumn{4}{|l|}{ 各種判定結果 } \\
\hline プレフレイル．人（\%) & $45(39.4)$ & $32(39.0)$ & $13(40.6)$ \\
\hline フレイル. 人 $(\%)$ & $1(0.8)$ & $1(1.2)$ & $0(0.0)$ \\
\hline プレサルコペニア．人（\%) & $36(31.5)$ & $26(31.7)$ & $10(31.2)$ \\
\hline サルコペニア．人（\%） & $5(4.3)$ & $5(6.1)$ & $0(0.0)$ \\
\hline
\end{tabular}

数值: 平均土標準偏差, 人数 (\%). RT class: Resistance Training class, AD class: Aerobics Dance class, SMI: Skeletal Muscle Mass Index, JST-IC: Japan Science and Technology Agency Index of Competence 
表 2 プレフレイル判定者の判定内訳

\begin{tabular}{lc}
\hline & 全体 $(\mathrm{n}=45)$ \\
\hline 体重減少.人 $(\%)$ & $26(57.7)$ \\
疲労感あり．人 $(\%)$ & $25(55.5)$ \\
筋力低下.人 $(\%)$ & $5(11.1)$ \\
歩行速度低下. 人 $(\%)$ & $2(4.4)$ \\
身体活動低下. 人 $(\%)$ & $2(4.4)$ \\
\hline
\end{tabular}

重複して判定されている対象者含む

ア判定結果は, プレフレイル $39.4 \%$, フレイル $0.8 \%$, プレサルコペニア $31.5 \%$ ，サルコペニア $4.3 \%$ サあっ た。また，プレフレイルと判定された45名の判定内訳 は体重減少 $57.7 \%$, 疲労感あり $55.5 \%$, 筋力低下 $11.1 \%$, 歩行速度低下 $4.4 \%$, 身体活動低下 $4.4 \%$ あ゙あた（表 2 )。

健常群とプレフレイル群の比較では, 過去 1 年間に 入院歴あり, 生活マネジメント, JST 合計の項目に有 意差を認めた（表 3 )。健常群とプレサルコペニア群
の比較では全ての項目に有意差を認めなかった（表 4$)$ 。 健常群とプレフレイルの比較で有意差を認めた過去 1 年間に入院歴あり・生活マネジメント・JST 合計を 独立変数, 年齢・性別を調整因子としたロジスティッ ク回帰分析の結果, 過去 1 年間に入院歴あり（オッズ 比4. 12 : 95\%信頼区間1.10-15.44）と生活マネジメ ント（オッズ比0.51：95\%信頼区間0.32-0.82）が抽 出された（表 5 )。

\section{IV. 考 察}

本研究は通年開催の介護予防教室参加者に対してフ レイル・サルコペニアの発生状況を調査した。また, プレフレイルに関連する因子の抽出を行った。

本研究対象者のプレフレイル・フレイル判定割合は $39.4 \% \cdot 0.8 \%$ であり, 全国でのプレフレイル・フレ イルの判定割合（プレフレイル； $51.2 \%$ ・フレイ 11. $2 \%)^{111}$ に比べ，どちらも下回っていた。また，本

表 3 健常群とプレフレイル群の比較

\begin{tabular}{|c|c|c|c|}
\hline & $\begin{array}{l}\text { 健常群 } \\
(\mathrm{n}=68)\end{array}$ & $\begin{array}{c}\text { プレフレイル群 } \\
(\mathrm{n}=45)\end{array}$ & $\mathrm{p}$ 值 \\
\hline 年齢。歳 & $73.07 \pm 4.51$ & $73.13 \pm 4.74$ & 0.946 \\
\hline 女性. 人（\%） & $49(72.1)$ & $32(71.1)$ & 0.913 \\
\hline \multicolumn{4}{|l|}{ アンケート結果 } \\
\hline 現在通院中の疾患あり。人（\%） & $36(52.9)$ & $30(66.6)$ & 0.147 \\
\hline 過去 1 年間に入院歴あり。人（\%) & $4(5.9)$ & $8(17.8)$ & 0.046 \\
\hline 配偶者あり。人（％） & $48(70.6)$ & $31(68.9)$ & 0.847 \\
\hline 喫煙習慣あり。人（\%） & $3(4.4)$ & $2(4.4)$ & 0.665 \\
\hline 飲酒習慣あり。人（\%) & $14(20.6)$ & $8(17.8)$ & 0.712 \\
\hline \multicolumn{4}{|l|}{ JST-IC } \\
\hline 新機器利用. 点 & $3.65 \pm 0.66$ & 3. $44 \pm 0.94$ & 0.183 \\
\hline 情報収集. 点 & $3.37 \pm 1.04$ & $3.13 \pm 0.81$ & 0.204 \\
\hline 生活マネジメント．点 & $3.43 \pm 0.72$ & $2.96 \pm 1.04$ & 0.005 \\
\hline 社会参加. 点 & $2.34 \pm 1.38$ & $2.09 \pm 1.22$ & 0.321 \\
\hline 合計. 点 & $12.16 \pm 2.80$ & $12.64 \pm 2.51$ & 0.028 \\
\hline \multicolumn{4}{|l|}{ 介護予防教室参加状況 } \\
\hline RT class. 人 $(\%)$ & $22(32.3)$ & $16(35.5)$ & 0.724 \\
\hline 参加教室 AD class. 人（\%) & $43(63.2)$ & $25(55.5)$ & 0.414 \\
\hline $\mathrm{RT}$ and $\mathrm{AD}$ class. 人 (\%) & $3(4.4)$ & $4(8.8)$ & 0.434 \\
\hline 参加頻度 1 回以上／週. 人（\%） & $52(76.5)$ & $35(77.8)$ & 0.872 \\
\hline 参加期間 6 ヶ月以上経過. 人 (\%) & $53(77.9)$ & 33 (73. 3) & 0.574 \\
\hline
\end{tabular}

数值：平均土標準偏差，人数 (\%). 年齢・JST-IC（社会参加・合計）は Mann-Whitney の U 検定 JST-IC (新機器利用・情報収集・生活マネジメント) はStudent の $\mathrm{t}$ 検定

性別・アンケート（現在通院中の疾患あり・配偶者あり・飲酒習慣あり）・ 介護予防教室参加状況（RT class · $\mathrm{AD}$ class $\cdot$ 参加頻度 $・$ 参加期間) はカイ二乗検定

アンケート（過去 1 年間に入院歴あり・喫煙習慣あり）・介護予防教室参加状況（RT and AD class）は Fisher の直接確率検定

JST-IC: Japan Science and Technology Agency Index of Competence, RT class: Resistance Training class, AD class: Aerobics Dance class 
表 4 健常群とプレサルコペニア群の比較

\begin{tabular}{|c|c|c|c|}
\hline & $\begin{array}{l}\text { 健常群 } \\
(\mathrm{n}=73)\end{array}$ & $\begin{array}{c}\text { プレサルコペニア群 } \\
(\mathrm{n}=36)\end{array}$ & $\mathrm{p}$ 值 \\
\hline 年齢. 歳 & $72.7 \pm 4.6$ & $73.6 \pm 4.6$ & 0.315 \\
\hline 女性. 人（\%） & $51(69.9)$ & $26(72.2)$ & 0.799 \\
\hline \multicolumn{4}{|l|}{ アンケート結果 } \\
\hline 現在通院中の疾患あり。人（\%） & $41(56.2)$ & $22(61.1)$ & 0.623 \\
\hline 過去 1 年間に入院歴あり。人（\%) & $10(13.7)$ & $2(5.6)$ & 0.172 \\
\hline 配偶者あり。人（\%） & $53(72.6)$ & $22(61.1)$ & 0.223 \\
\hline 喫煙習慣あり。人（\%) & $4(54.7)$ & $1(27.7)$ & 0.464 \\
\hline 飲酒習慣あり。人（\%) & $18(24.7)$ & $4(11.1)$ & 0.097 \\
\hline \multicolumn{4}{|l|}{ JST-IC } \\
\hline 新機器利用. 点 & $3.55 \pm 0.78$ & $3.64 \pm 0.72$ & 0.550 \\
\hline 情報収集．点 & 3. $21 \pm 1.04$ & $3.44 \pm 0.77$ & 0.225 \\
\hline 生活マネジメント。点 & $3.18 \pm 0.89$ & 3. $31 \pm 0.92$ & 0.494 \\
\hline 社会参加. 点 & $2.23 \pm 1.37$ & $2.25 \pm 1.25$ & 1. 000 \\
\hline 合計. 点 & $12.16 \pm 2.80$ & $12.64 \pm 2.51$ & 0.425 \\
\hline \multicolumn{4}{|l|}{ 介護予防教室参加状況 } \\
\hline RT class. 人 $(\%)$ & $29(39.7)$ & $9(25)$ & 0.129 \\
\hline 参加教室 AD class. 人 (\%) & $39(53.4)$ & $25(69.4)$ & 0.110 \\
\hline RT and AD class.人（\%) & $5(6.8)$ & $2(5.5)$ & 0.578 \\
\hline 参加頻度 1 回以上／週. 人（\%) & $57(78.1)$ & $27(75)$ & 0.719 \\
\hline 6 ヶ月以上経過. 人 $(\%)$ & $57(78.1)$ & $27(75)$ & 0.719 \\
\hline
\end{tabular}

数值：平均土標準偏差，人数 $(\%)$. 年齢·JST-IC（社会参加・合計）は Mann-Whitney のU 検定

JST-IC (情報収集) はStudent $の \mathrm{t}$ 検定

JST-IC（新機器利用・生活マネジメント）は Welch の t 検定

性別・アンケート（現在通院中の疾患あり・配偶者あり・飲酒習慣あり）・ 介護予防教室参加状況（RT class · $\mathrm{AD}$ class $\cdot$ 参加頻度 $\cdot$ 参加期間）はカイ二乗検定

アンケート（過去 1 年間に入院歴あり・喫煙習慣あり）・介護予防教室参加状況（RT and AD class）は Fisher の直接確率検定

JST-IC: Japan Science and Technology Agency Index of Competence, RT class: Resistance Training class, AD class: Aerobics Dance class

表 5 プレフレイルの有無を従属変数としたロジスティック回帰分析の結果

\begin{tabular}{lcccc}
\hline & オッズ比 & $95 \% \mathrm{CI}$ 下限 & $95 \% \mathrm{CI}$ 上限 & $\mathrm{p}$ 值 \\
\hline 生活マネジメント & 0.512 & 0.32 & 0.82 & 0.006 \\
過去 1 年間に入院歴あり & 4.126 & 1.102 & 15.447 & 0.035 \\
\hline
\end{tabular}

Hosmer-Lemeshow 検定 $\mathrm{p}=0.559$

判別的中率 $64.6 \%$

投入変数：過去 1 年間に入院歴あり，生活マネジメント, JST-IC 合計, 性別, 年齢

研究対象者のプレサルコペニア・サルコペニア判定割 合は $31.5 \% \cdot 4.3 \%$ あ゙り, 全国でのプレサルコペニ ア・サルコペニアの判定割合（プレサルコペニア； $31.8 \%$ サルコペニア；7.5\% (2,13) と比較するとプレ サルコペニアは同程度であり，サルコペニアは下回っ ていた。本研究でのプレフレイル対象者の判定内訳は 筋力低下が $11.1 \%$, 歩行速度低下が $4.4 \%$, 身体活動

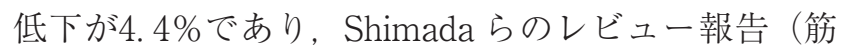
力低下；22.6\%, 歩行速度低下；21.0\%, 身体活動低 下；21.2\% (11)に比べ低い割合であった。一方，本研
究のプレフレイル対象者の体重減少と疲労感は, それ ぞれ $57.7 \%$ と5.5\%であり，前述のレビュー報告（体 重減少； 15.5\%，疲労感あり；22.6\% $)^{11}$ よりも高い 割合であった。本研究の対象である通年開催の介護予 防教室参加者は教室にて運動を 6 ケ月以上継続してい るものが75.4\%であり継続的な運動習慣を有している ため, 握力や歩行速度を維持できておりフレイル・サ ルコペニアと判定される割合が少なかったものと推察 できる。しかしながら, プレフレイル判定者では体重 減少や疲労感のある対象者が多く存在することから, 
運動介入だけでなく体重管理や疲労感に対する介入も 必要であることが示唆された。

次にプレフレイルに関連する因子を抽出した結果, 生活マネジメントと過去 1 年間に入院歴ありがそれぞ れ独立した因子として抽出された。JST-IC の下位領 域である生活マネジメントは, 生活マネジメントとい う新たな能力の側面を評価しているとされており ${ }^{14)}$, この生活マネジメントに必要な能力がプレフレイルの 有無に密接に関連しているといえる。生活マネジメン トについて，鈴木ら ${ }^{14)}$ は「IADLレベルの活動よりは 高度であるが, 家族の世話や未知の場所への移動, 安 全の確保といった家庭生活を支障なく営むために必要 な活動」と述べている。このことから, 生活マネジメ ントを行うためには，自身の活動のみならず，他者の 行動をも管理するという身体的側面，精神心理的側面， 社会的側面を高次に複合した能力が必要であることが わかる。プレフレイルは身体的側面，精神心理的側面， 社会的側面をも含む概念であるフレイル ${ }^{15}$ の前駆状態 であることから生活マネジメントが関連因子として抽 出されたと考えられる。

過去 1 年間の入院歴とプレフレイルとの関連性につ いては, 入院経験は, 身体の恒常性が何らかの原因で 破綻し，集中的な治療を必要とした状態である。よっ て，症状が改善した場合でもプレフレイルを呈してい る可能性は十分に考えられる。また，松田ら ${ }^{16}$ は女性 前期高齢者に対してプレフレイルの関連因子を抽出し た結果，健康意識が有意な因子(オッズ比0.527：95\% 信頼区間0.283-0.981, $\mathrm{p}<0.05)$ であったと述べて おり, 入院歴が対象者へ低い健康意識を生じさせ，そ の結果プレフレイルに関連する因子として抽出された 可能性も示唆された。

本研究の結果, 通年開催の介護予防教室参加者のフ レイル・サルコペニア判定割合は全国平均と比較して 低い割合であった。また，プレフレイルに関連する因 子として過去 1 年間に入院歴ありと生活マネジメント が抽出されており, 対象者の健康状態と生活マネジメ ント能力に焦点を当てた予防・介入の必要性が示唆さ れた。

\section{謝 辞}

本研究を実施するにあたり，測定に協力をいただき ました茨木市介護予防教室参加者の皆様, 茨木市関連 課の皆さまに深謝申し上げます。

\section{引用文献}

1）内閣府：平成29年度版高齢社会白書. http://www 8.cao.go. jp/kourei/whitep-aper/w-2017/zenbun/29 pdf_index.html (2018年 6 月10日閲覧)

2) 葛谷雅文 : 老年医学における Sarcopenia\&Frailtyの重要 性. 日老医誌, 2009, 46(4)：279-285.

3) Fried LP,Tangen CM,Walston J,et al: Frailty in older adults: evidence for a phenotype.J Gerontol A Biol Sci Med Sci, 2001, 56(3): M146-156

4) Xue QL, Bandeen-Roche K, Varadhan R, et al: Initial manifestations of frailty criteria and the development of frailty phenotype in the women's health and aging study. J Gerontol A Biol Sci Med Sci, 2008, 63(9): 984-990.

5) Cruz-Jentoft AJ, Baeyens JP, Bauer JM, et al: Sarcopenia: European consensus on definition and diagnosis.Report of the European Working Group on Sarcopenia in Older People.Age and Aging, 2010, 39: 412-23.

6) Iwasa $\mathrm{H}$, Masui $Y$, Inagaki $\mathrm{H}$, et al:Assessing competence at a higher level among older adults:development of the Japan Science and Technology Agency Index of Competence (JST-IC). Aging Clin Exp Res, 2018, 30: 383-393.

7) Iwasa $H$, Masui $Y$, Inagaki $H$, et al: Development of the Japan science and technology agency index of competence to assess functional capacity in older adults: Conceptual Definitions and Preliminary Items. Gerontology and Geriatric Medicine, 2015, 1: 2333721415609490, doi: 10. 1177/ 2333721415609490.

8）鈴木隆雄, 大渕修一（監修）：指導者のための介護予防完 全マニュアル 包括的なプラン作成のために。財団法人 東京都高齢者研究・福祉振興財団 (編)。財団法人 東京 都高齢者研究・福祉振興財団, 東京, 2004， 19-54.

9）佐竹昭介：長寿医療研究開発費 平成27年度総括研究報告 （総合報告及び年度報告）フレイルの進行に関わる要因に 関する研究 (25-11).

www.ncgg.go.jp/ncgg-kenkyu/documents/27/25 xx-11.pdf (2018年 6 月10日閲覧)

10) Chen LK, Liu LK, Woo J, et al: Sarcopenia in Asia: consensus report of the Asian working group for sarcopania, J Am Med Dir Assoc, 2014, 15:95-101.

11) Satake S, Shimada H, Yamada M, et al:prevalence of frailty among community-dwellers and outpatients in Japan as defined by the Japanese version of the cardiovascular health study criteria.Geriatr Gerontol Int, 2017, 17(12): 2629-2634.

12) Yoshida D, Suzuki T, Shimada H, et al: Using two different algorithm to determine the prevalence of sarcopenia. Geriatr Gerontol Int, 2014, 14: 46-51.

13) Yuki A, Ando F, Otsuka R, et al: Epidemiology of sarcopenia in elderly Japanese. J Phys Fitness Sports Med, 2015, 4(1): 111-115.

14）鈴木隆雄, 増井幸恵, 稲垣宏樹 - 他 : 戦略的創造研究推進 事業（社会技術研究開発）コミュニティで創る新しい高齢 社会のデザイン研究開発プロジェクト「新たな高齢者の健 康特性に配慮した新たな活動能力指標の開発」研究開発実 施終了報告書. 社会技術開発センター。 2013. 
https://ristex.jst.go.jp/examin/ko-rei/program/pdf/H24 houkoku_suzuki.pdf (2018年 6 月10日閲覧)

15）日本老年医学会：フレイルに関する日本老年医学会からの ステートメント.

https://www.jpn-geriat-soc.or.jp/info/topics/pdf/20140513 _01_01.pdf（2018年10月24日閲覧）

16）松田憲亮，池田 翔，鶴 大輔・他：女性前期高齢者にお けるプレフレイルの関連要因の検討。理学療法科学, 2018, 33(1): 159-163. 